\title{
OPTIMIZATION OF THE BIOAGENT Bacillus subtilis BIOMASS PRODUCTION AND ANTIBOSIS AGAINST
} Acremonium strictum

\author{
Ali, M.A. (1) Ettimad A.H. Osman(2), Ensaf I. Dawoud(1); \\ Thanaa F. Ibrahim ${ }^{(2)}$ and G.A. Amin ${ }^{(1)}$ \\ (1) Agric. Microbiology Dept., Fac. Of Agric. Cairo Univ., Egypt. \\ (2) Maize, Sugar and Forage Crops Dis. Res. Dept, Plant Pathol. Res. \\ Inst., Agric. Res. Center, Giza
}

\begin{abstract}
All $A$. stritum strains, isolated from grain sorghum plants showing Acremonium wilt disease symptoms, varied in their virulence on both tested grain sorghum genotype with the superiority of strain No. 2.

Among 5 different recommended media, King's medium was the most favorable one for propagation and highest antagonistic activity of Bacillus subtilis, previously isolated from rhizosphere of resistant grain sorghum cultivar (Dorado) against $A$. strictum.

The optimum environmental conditions needed for $B$. subtilis to give maximum antagonistic efficiency against $A$. strictum were $48 \mathrm{~h}$ incubation period, 30$35^{\circ} \mathrm{C}$ incubation temperature and $\mathrm{pH}$ 7.0. in shake-flask submerged culture. Sucrose $\left(9.0 \mathrm{~g} \mathrm{.l}^{-1}\right)$ and $\mathrm{KNO}_{3}\left(20 \mathrm{~g} \mathrm{.}^{-1}\right)$ were the best carbon and nitrogen sources, respectively.

Utilization of agro-industrial wastes for $B$. subtilis propagation in modified King's medium showed that glucose syrup and corn steep liquor as cheap carbon and nitrogen sources, respectively supported the highest antagonistic potential of $B$. subtilis using shake-flask submerged culture.

Keywords: Bacillus subtilis, Biological control, Acremonium wilt, Acremonium strictum, Agro-industrial wastes, Antifungal activity, Optimization, Propagation.
\end{abstract}

\section{INTRODUCTION}

Grain sorghum (Sorghum bicolor L. Moench) occupies a unique position among cereal crops in Egypt and all over the world. It is used mostly as food and feed in addition to its importance in several fermentation industries such as beverages and biofuels (Ratnadass et al., 2003). Grain sorghum is vulnerable to different fungal diseases of which Acremonium wilt, caused by the soil-borne fungus Acremonium strictum W. Gams (Cephalosporium acremonium corda), which is responsible for crop yield losses of up to 50\% (Ibrahim and Zein El-Abedeen, 2000 and Osman, 2004).

Biological control of plant pathogens, based on the management of a natural source to develop the antagonistic activity against harmful organisms, common component of ecosystems, is currently accepted as a key practice in sustainable griculture and as potential alternative to the intensive use of chemical pesticides which are harmful to the environment. Several investigators reported the use of biological control against soil-borne diseases (El-Kazzaz et al., 2000 and Chincholkar and Mukerji, 2007).

Bcillus subtilis has been used as bicontrol agent for many soil-borne diseases such as late wilt of maize (Ibrahim, 1990), sesamum root-rot 
(Dinakaran et al., 1995) stem-rot of ground nut (Kulkarni et al., 1996), Fusarium wilt in tomato (Sarhan et al., 2001), Acremonium wilt of grain sorghum (Ali et al., 2005) and sugar beet damping-off (Abo-Elnaga, 2006).

In the literature several media were used for propagation of $B$. subtilis with enormous variation among obtained results with respect to growth and antagonistic potential (Ezzat et al., 2001 and Abd-Alla et al., 2003).

Nutritional and environmental parameters influence markedly microbial metabolism and production of antifungal substances. Certainly, this is the case with $B$. subtilis. Thus, optimization of these parameters may led to strain improvement which may enhance antagonistic activity and open the possibilities of efficient disease control.

The present work aimed to optimize cultural conditions for propagation and supporting antagonistic potential of $B$. subtilis against $A$. strictum the incitant of grain sorghum Acremonium wilt. Here, incorporation of some agro-industrial wastes in the propagation medium was investigated.

\section{MATERIALS AND METHODS}

\section{Bacterial candidate}

Bacillus subtilis, a promising antagonistic strain against grain sorghum Acremonium wilt disease (Osman, 2004) was used in this study. It was maintained refregerated on nutrient agar medium (Jacobs and Gerstein, 1960).

\section{Sorghum grains}

Grains of two susceptible grain sorghum genotypes (Giza 113 and Giza 15) obtained from Sorghum Res. Dept., Field Crops Res. Inst., ARC, Giza, Egypt, were used for carrying out the pathogenicity test under greenhouse conditions.

\section{Agro-industrial wastes and by-products}

Sugar-cane molasses, obtained from Sugar and Integrated Industries Company, El-Hawamedia, Giza, and sugar beet molasses, obtained from Delta Sugar Company, Kafer El-Shikh, were clarified according to Pyke (1958) and kept refrigerated until use. Glucose syrup, corn steep liquor and glutovin were kindly provided by Egyptian Company of Starch and Glucose, Torah, Cairo while soybean cake was obtained from Food Processing Unit, ARC, Giza. Corn steep liquor was clarified according to Dokhan (2005) before use while glutovin and soybean cake were subjected to acid hydrolysis according to Ahmed et al. (1992) and the hydrolyzates were kept refrigerated until use.

\section{Isolation and identification of the phytopathogen}

Plant samples of grain sorghum showing acremonium wilt disease symptoms were collected from different governorates in middle and upper Egypt. The lower internodes ( $3^{\text {rd }}-5^{\text {th }}$ above soil level) of the rotted stalks of the wilted plants were washed with running water and left to dry, surface sterilized by ethanol (70\%), flamed and peeled under aseptic conditions. Small pieces of the internal tissues were cut out and plated on PDA medium (Booth, 1971) containing streptomycin (200 ppm). Plates were incubated at $30^{\circ} \mathrm{C}$ for 3-7 days and examined daily for the occurance of fungal growth. The 
growing fungi were examined miroscopically and purified using single spore technique.

The obtained fungal isolates were identified by morphological characteristics and microscopic examination according to Barnett (1960) and the specifications of Sabet et al. (1966a) and confirmed by comparing these isolates with the culture collection of the Maize, Sugar and Forage Crops Res. Dept., Plant Pathol. Res. Inst., ARC, Giza, Egypt. The isolates were maintained on PDA slants under mineral oil in a refrigerator for further studies.

\section{Virulence of Acremoium strictum strains}

The virulence of $12 A$. strictum strains was carried out under greenhouse conditions using soil infestation technique. Two susceptible grain sorghum cultivars (Giza 113 and Giza 15) were used. The phytopathogenic inoculants were prepared by growing the obtained $A$. strictum strains separately in sterilized glass bottles of $500 \mathrm{ml}$ capacity, each containing 100 $\mathrm{g}$ sorghum grains moistened with $50 \mathrm{ml} \mathrm{H} \mathrm{H}_{2} \mathrm{O}$ for 15 days at $30^{\circ} \mathrm{C}$. Bottles were shaken every 2 days for homogenicity.

Soil infestation was carried out by adding the previously prepared inoculant of each strain at the rate of $100 \mathrm{~g}^{\text {. pot }}{ }^{-1}$ to sterilized clay pots (25 $\mathrm{cm}$ diameter) filled with autoclaved Nile silt soil prior to sowing as described by Sabet et al. (1966b). Untreated soil was used as control. Sorghum grains were surface sterilized using sodium hypochlorite solution (5\%) for 2 minutes. Five seeds were sown in each pot and 4 replicates were allocated. Superphosphate $\left(15.5 \% \mathrm{P}_{2} \mathrm{O}_{2}\right)$ was added at the rate of $3.0 \mathrm{~g}$. pot ${ }^{-1}$ before sowing. Plants were fertilized 21 days after sowing at the rate of $3.0 \mathrm{~g}$ urea $(46.5 \% \mathrm{~N})$ and $3.0 \mathrm{~g}$ potassium sulphate $\left(48 \% \mathrm{~K}_{2} \mathrm{O}\right)$ per pot. Irrigation was done when necessary using tap water. Disease monitoring was recorded after 90 days of sowing as percentage of wilted plants.

Re-isolation of the pathogenic fungal isolates from diseased plants was carried out to meet Koch's postulates.

\section{Estimation of $B$. Subtilis growth}

Bacillus subtilis growth was determined turbidimetrically as follows: a loopful of $48 \mathrm{~h}$-old culture was transferred into $50 \mathrm{ml}$ sterilized nutrient broth in $250 \mathrm{ml}$ - conical flask and incubated on a rotary shaker incubator at 150 rpm and $25^{\circ} \mathrm{C}$ for $48 \mathrm{~h}$. After incubation period, bacterial cells were counted as cfu. $\mathrm{ml}^{-1}$ broth culture by plate count technique (using nutrient agar medium, $25^{\circ} \mathrm{C}$ for $48 \mathrm{~h}$ ). Optical density (OD) of each broth culture dilution, with known bacterial count, at $620 \mathrm{~nm}$ was recorded using Perkin Elemer 55 E spectrophotometer. Bacterial growth (cfu. $\mathrm{ml}^{-1}$ ) was determined by multiplication of sample OD at $620 \mathrm{~nm}$ by slope-1 of relation line plotted between bacterial count (cfu. ml-1) and OD at $620 \mathrm{~nm}$.

\section{In vitro estimation of $B$. subtilis antagonistic potential against $A$. strictum}

Antagonistic potential of $B$. subtilis culture filtrate against $A$. strictum was determined using well cut-diffusion technique (Brock, 1973). After incubation period, cultures were centrifuged at $3000 \mathrm{rpm}$ for $20 \mathrm{~min}$. The supernatants were then filter sterilized using sterile syringe filter of $25 \mathrm{~mm}$ in diameter and $0.2 \mu \mathrm{m}$ pore size. Wells $(5 \mathrm{~mm}$ in diameter) were made 
equidistantly from each other in $9 \mathrm{~cm}$ - Petri plates containing PDA supplemented with $0.5 \%$ peptone medium seeded with $A$. strictum $\left(3 \times 10^{4}\right.$ spores. $\mathrm{ml}^{-1}$ ) using sterile cork borer. Then, $0.2 \mathrm{ml}$ of each culture filtrate was transferred separately into each well using sterile micropipette. The plates were then incubated for 5 days at $30^{\circ} \mathrm{C}$ before measuring the inhibition zone diameters. Absolute unit of inhibition zones (AU) were calculated as follows: $A U=Y^{2} / X^{2}$ where: $Y$ is the radius of inhibition zone diameter and $X$ is the radius of the well.

Optimization of cultivation conditions for magnifying of $B$. subtilis growth and antagonistic potential.

In order to optimize nutritional and environmental conditions to support $B$. subtilis growth and antagonistic potential against $A$. strictum, 8 sets of experiments were conducted using shake-flask submerged culture: a conical flasks of $250 \mathrm{ml}$ capacity containing $50 \mathrm{ml}$ sterilized medium were inoculated with a loopful of $B$. subtilis, $48 \mathrm{~h}$-old culture. The inoculated flasks were incubated on shaker incubator at $150 \mathrm{rpm}$ and $30^{\circ} \mathrm{C}$ for $72 \mathrm{~h}$. At the end of incubation period, the bacterial growth and antagonistic potential were determined as previously mentioned.

To select for the most favorable basal medium, 5 different recommended media [Czapek-Dox (Thom and Raper, 1945), King (King et al., 1945) potato-dextrose (Booth, 1971), nutrient broth (Stanisich and Holloway, 1972) and Richard (Richard, 1954)] were tested. Time course of cell growth and antagonistic potential were examined up to $84 \mathrm{~h}$ incubation period. Optimum $\mathrm{pH}$ and incubation temperature were also studied using King's medium with initial $\mathrm{pH}$ values of $5.5,6.0,6.5,7.0,7.5$ and 8.0 and different incubation temperatures of $25,30,35,40$ and $45^{\circ} \mathrm{C}$. The carbon (glucose, mannose, sucrose, maltose, lactose and corn starch) and nitrogen $\left[\left(\mathrm{NH}_{4}\right)_{2} \mathrm{SO}_{4}, \mathrm{NH}_{4} \mathrm{Cl}, \mathrm{NaNO}_{3}, \mathrm{KNO}_{3}\right.$, urea, peptone and yeast extract] sources were examined. The most favorable concentrations of carbon $(3,6,9,12$ and $15 \mathrm{g.l}^{-1}$ sucrose) and nitrogen (5, 10, 15, 20, 25 and $\left.30 \mathrm{g.l}^{-1} \mathrm{KNO}_{3}\right)$ sources were also investigated.

Utilization of some agro-industrial by-products as carbon and nitrogen sources

Some agro-industrial by-products, sugar cane molasses, sugar beet molasses and glucose syrup (as carbon sources) and corn steep liquor, glutovin and soybean cake (as nitrogen sources) replaced sucrose and $\mathrm{KNO}_{3}$, respectively, in order to obtain an economic medium for propagation of B. subtilis.

\section{Statistical analysis}

Statistical analysis was computed using analysis of variance procedure described by Sendecor and Cochran (1980), the significant mean differences between treatment means were separated by Duncan's Multiple Range Test (Duncan, 1955).

\section{RESULTS AND DISCUSSION \\ Isolation and identification of the phytopathogen \\ The most prevalent fungi (12 isolates) were isolated from samples of grain sorghum plants, showing Acremonium wilt disease symptoms, collected}


from seven governorates in middle and upper Egypt. All isolates exhibited the same identical characteristics. Their growth on PDA supplemented with $0.2 \%$ yeast extract at $28^{\circ} \mathrm{C}$ was moderately rapid covering the plate surface in about 15 days. They produced a dense mycelial mat with a distinctly raised smooth margin. The hyphae were hyaline, septate, slender and simple varying in length. Conidia were hyaline, single-celled, oval, straight or slightly curved produced at the tip of the conidiophore and collected to form spore heads embedded in a slime matrix. When compared with those reported by Barnett (1960) and Sabet et al. (1966a) for Acremonium strictum, they were in conformity. Therefore, the isolates were all identified as $A$. strictum, the well known causal pathogen of Acremonium wilt of grain sorghum. The isolated fungus is very similar to Cephalosporium acremonium which was isolated from wilted grain sorghum plants (El-Shafey et al., 1979 and Ali et al., 2004) and was the causal pathogen of Acremonium wilt disease for American sorghum cultivars (Natural et al., 1982) and Chinese grain sorghum ones (Xu et al., 1995).

\section{Virulence of Acremonium strictum}

Results illustrated in Figure (1) show that the tested strains varied in their virulence and the infection was a cultivar dependent. Genotype Giza 113 was less susceptible to $A$. strictum strains (30-93.5\% infection) with a mean infection percentage of 45.29 whereas Giza 15 was more susceptible (50$97.5 \%$ ) with a mean infection percentage of 60.63 . Strain No 2 isolated from Giza governorate (Ayat) was the most aggressive, causing the highest infection percentage (97.5 and 93.5) on Giza 15 and Giza 113, respectively with a mean infection percentage of 95.5. Differences in virulence between $A$. strictum strains indicate that different pathotypes of this pathogen may exist (William and Asher, 1996 and Osman, 2004).

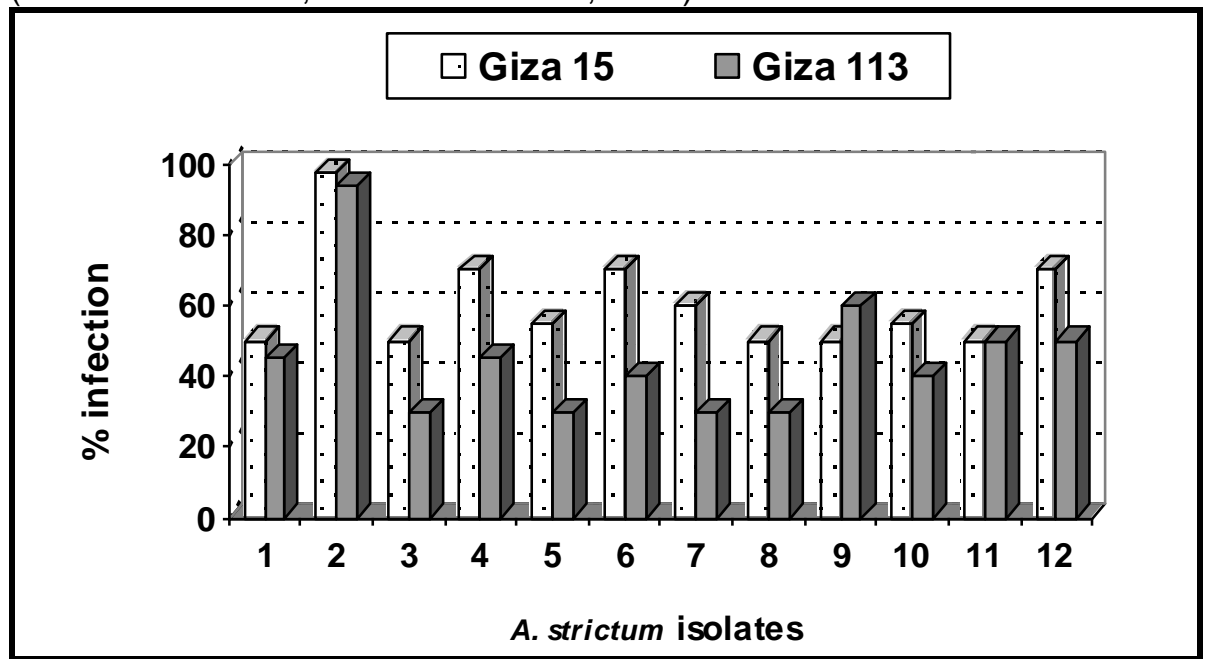

Figure 1:Virulence of $A$. strictum strains against two susceptible [grain sorghum genotypes under greenhouse conditions. 
Ali, M.A.et al.

Similarly, El-Assiuty (1982) found that some strains of C. acremonium causing stalk rot disease of grain sorghum were more virulent than others. On the other hand, sorghum and maize varieties showed a wide susceptibility to $C$. acremonium strains and could be classified into 6 major categories according to their degree of infection (Mansour et al., 1986). Also, El-Shafey et al. (1999) recorded highly significant variation in virulence of large number of $A$. strictum strains when their pathogenicity was tested on four grain sorghum cultivars under greenhouse conditions. On the other hand, Giza 15 was the most susceptible genotype.

For the superiority of strain No 2 among all tested $A$. strictum strains in respect to its infection of both susceptible genotypes, it was selected for further studies.

Optimization of cultivation conditions for enhancement of $B$. subtilis growth and antagonistic potential against $A$. strictum

A comparative study was carried out to gain some more antagonistic potential of the promising antaognsitic B. subtilis strain (Osman, 2004) against $A$. strictum.

\section{Selection of suitable medium}

Cultivation of $B$. subtilis was undertaken in five different recommended media using shake-flask submerged culture. Data illustrated in Figure (2) show that nutrient broth is the most suitable medium for growth of B. subtilis $\left(30 \times 10^{7} \mathrm{cfu} . \mathrm{ml}^{-1}\right)$ followed by King's and Richard's media $\left(28 \times 10^{7}\right.$ and $27 \times 10^{7}$, respectively), while King's broth is the most suitable for $B$. subtilis antagonistic potential against $A$. strictum expressed as absolute unit of inhibition zone (29.16 AU), followed by nutrient broth and potato dextrose media (23.04 and 21.16 AU, respectively). However, Czapek-Dox's broth was the least medium for both growth and antagonistic potential. These findings are in line with those obtained by Ezzat et al. (2001). In contradiction, Ibrahim (1990) reported that Czapek-Dox's broth was the best cultural medium for maximum antagonism by two different $B$. subtilis strains against Cephalosporium maydis. On the other hand, Abd-Alla et al. (2003) stated that Richard's medium was suitable for maximum antagonistic potential of $B$. subtilis against Sclerotium rolfsii. Such contradiction might be due to difference in bacterial strain, pathogen and/or other cultural conditions (AboElnaga, 2006). Therefore, King's medium was selected for further studies. 


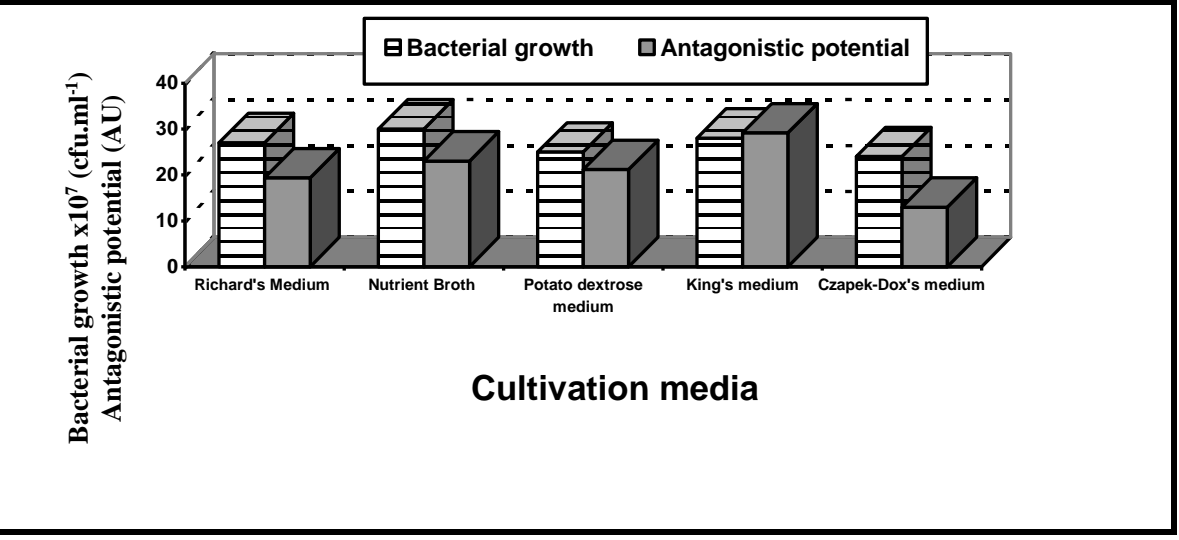

Figure 2: Selection of suitable cultivation medium for supporting growth and antagonistic potential expressed as absolute unit of inhibition zone (AU) of $B$. subtilis against $A$. strictum.

\section{Time course}

Time course of $B$. subtilis growth and antagonistic potential aganist $A$. strictum was investigated. Results illustrated in Figure (3) show that there was close association between bacterial growth and antifungal substance (s) production (expressed as $\mathrm{AU}$ ). Bacterial growth increased markedly with time to reach its maximal $\left(30 \times 10^{7} \mathrm{cfu}^{\mathrm{ml} \mathrm{I}^{-1}}\right)$ after $60 \mathrm{~h}$, then slightly decreased. In parallel, antagonistic potential of $B$. subtilis increased to reach its maximal (30.47 AU) after $48 \mathrm{~h}$, then also slightly decreased. The obtained results were similar to those reported by Ibrahim (1990) and Ezzat et al. (2001) who stated that the highest antifungal production by $B$. subtilis was two days of incubation in buffered medium at pH 7.0. Abd-Alla et al. (2003) mentioned that maximum antagonistic potential of $B$. subtilis against $S$. rolfsii was achieved at $72 \mathrm{~h}$ incubation period. Such difference might be attributed to variations in bacterial strain, pathogenic fungi and/or other cultural variations.

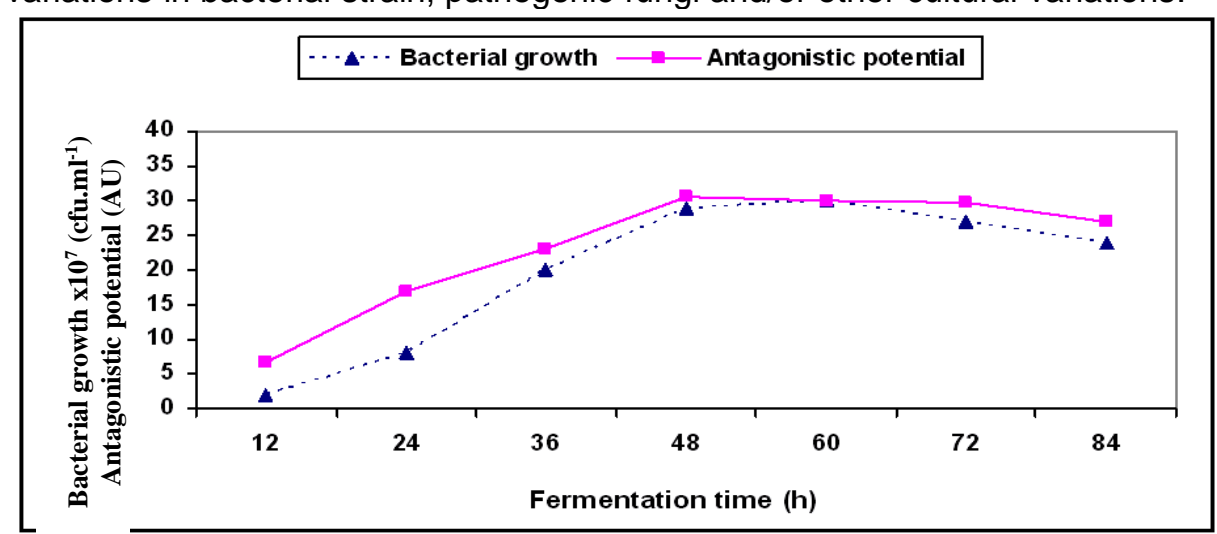

Figure 3: Time course of $B$. subtilis growth and antagonistic potential against $\boldsymbol{A}$. strictum expressed as absolute unit of inhibition zone (AU). 


\section{Effect of fermentation $\mathrm{pH}$}

Growth medium $\mathrm{pH}$ is considered to be one of the most important factors affecting the microbial growth and production of biologically active materials including anti-fungal substances (McKeen et al., 1986). Therefore, cultivation of $B$. subtilis was conducted in King's medium with six initial $\mathrm{pH}$ levels. Data illustrated in Figure (4) clearly show that antagonistic potential of $B$. subtilis gradually increased by increasing initial $\mathrm{pH}$ of the growth medium, reaching its maximal activity $(31.36 \mathrm{AU})$ at $\mathrm{pH}$ 7. then the antagonistic potential markedly decreased by increasing initial $\mathrm{pH}$ levels. These results are in consistence with those reported by Ezzat et al. (2001) and are generally in agreement with Ibrahim (1990) who stated that maximal antagonistic activity of two strains of $B$. subtilis, grown in Czapek-Dox's medium, against $C$. maydis was achieved at initial $\mathrm{pH}$ of 7.5. Abd-Alla et al. (2003) reported that maximum antagonistic activity of $B$. subtilis, grown in Richard's medium, against $S$. rolfsii was attained at initial $\mathrm{pH}$ of 6.0 . These variations are more likely attributed to certain variations the in bacterial strain, pathogenic fungus and/or other environmental and nutritional factors.

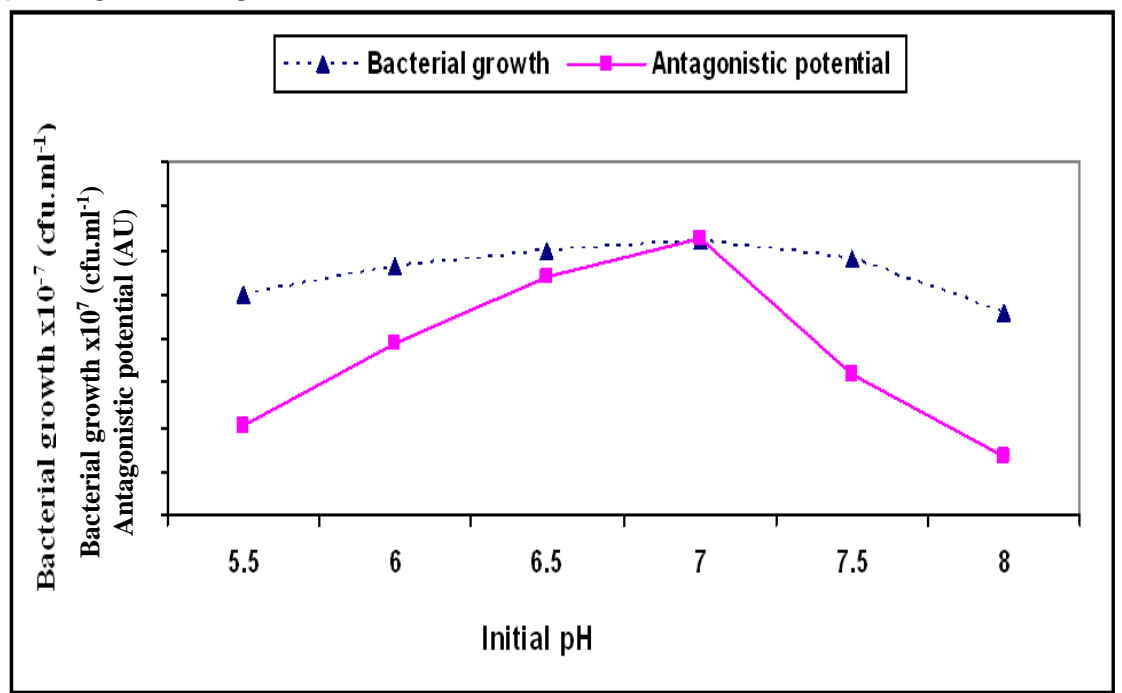

Figure 4: Effect of initial pH levels of the cultivation medium on growth and antagonistic potential of $B$. subtilis, expressed as absolute unit of inhibition zone (AU) against $A$. strictum.

\section{Effect of fermentation temperature}

Results in Figure (5) show the effect of fermentation temperature on growth and antagonistic potential of $B$. subtilis against $A$. strictum. Temperature ranging between 25 and $35^{\circ} \mathrm{C}$ supported cell growth and enhanced antagonistic activity. Higher temperature had a negative effect on both variables. The maximal antagonistic potentials of 33.64 and $32.49 \mathrm{AU}$ were attained in cultivations carried out at 30 and $35^{\circ} \mathrm{C}$, respectively. The obtained results are in a parallel line with Sellam et al. (1978) who stated that production of antifungal substance by $B$. subtilis against $C$. maydis was 
stimulated by growing the bacteria at $30-35^{\circ} \mathrm{C}$ in Czapek-Dox's medium. Abd Alla et al. (2003) achieved the highest antagonistic activity against $S$. rolfsii by B. subtilis at $35^{\circ} \mathrm{C}$ in Richard's medium.

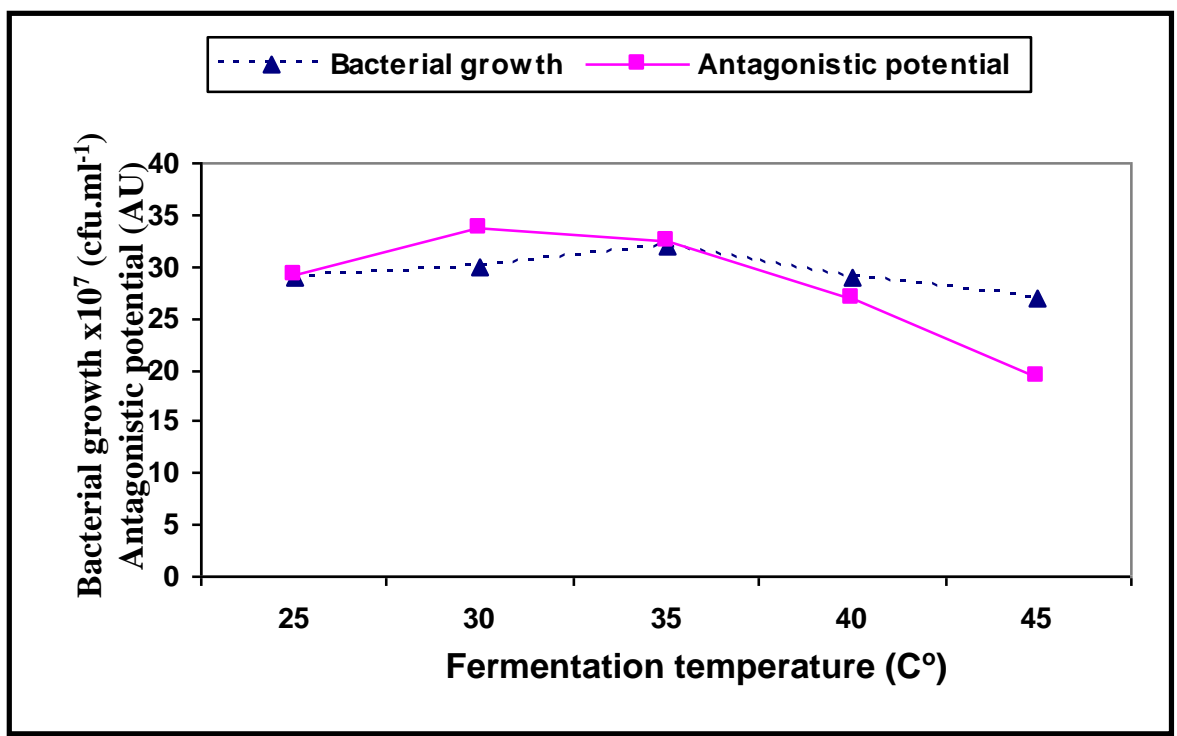

Figure 5: Effect of fermentation temperature on growth and antagonistic potential of $B$. subtilis against $A$. strictum expressed as absolute unit of inhibition zone (AU).

\section{Effect of carbon sources}

Seven different carbohydrates were tested as carbon sources to achieve maximal growth and antagonistic activity of $B$. subtilis against $A$. strictum. Table (1) reveals that sucrose supported the best performance of B.subtilis against $A$. stritcum (33.64 AU) followed by glucose and glycerol (32.49and $31.36 \mathrm{AU}$, respectively). Maximal bacterial growth $\left(32 \times 10^{7} \mathrm{cfu}^{\mathrm{ml}} \mathrm{l}^{-1}\right)$ was attained using glucose while, lactose supported the lowest bacterial

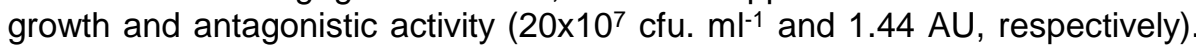
In agreement with the obtained results Abd-Alla et al. (2003) advocated sucrose to glucose for supporting $B$. subtilis antagonistic potential against $S$. rolfsii. 
Ali, M.A.et al.

Table 1:Effect of different carbohydrates as carbon sources on growth and antagonistic potential of Bacillus subtilis against $A$. strictum.

\begin{tabular}{|c|c|c|c|c|c|}
\hline \multirow[t]{2}{*}{ Carbon source ${ }^{(a)}$} & \multirow[t]{2}{*}{ Final pH } & \multirow{2}{*}{$\begin{array}{c}\text { Bacterial } \\
\text { growth X } 10^{7} \\
(\text { cfu.ml-1) }\end{array}$} & \multicolumn{3}{|c|}{$\begin{array}{l}\text { Antagonistic potential of } B \text {. subtilis } \\
\text { culture filtrate against } A \text {. strictum }\end{array}$} \\
\hline & & & $\mathrm{Y}(\mathrm{mm})$ & $\mathrm{Y}^{2}\left(\mathrm{~mm}^{2}\right)$ & $A U=Y^{2} / X^{2}$ \\
\hline Corn starch & 6.75 & 28 & 7.50 & 56.25 & 9.00 \\
\hline Glucose & 6.85 & 32 & 14.25 & 203.06 & 32.49 \\
\hline Mannose & 6.80 & 25 & 10.00 & 100.00 & 16.00 \\
\hline Sucrose & 6.80 & 30 & 14.50 & 210.25 & 33.64 \\
\hline Maltose & 6.40 & 28 & 9.00 & 81.00 & 12.96 \\
\hline Lactose & 6.10 & 20 & 5.00 & 25.00 & 4.00 \\
\hline Glycerol (control) & 7.00 & 29 & 14.00 & 203.06 & 31.36 \\
\hline
\end{tabular}

$Y$, radius of inhibition zone

$\mathrm{Au}$, absolute unit of inhibition zone

$X$, radius of the well $=2.5 \mathrm{~mm}$

(a), at the rate of $3.9 \mathrm{~g}$ carbon. $\mathrm{I}^{-1}$

\section{Effect of initial concentration of sucrose}

As shown in Figure (6), antagonistic potential of $B$. subtilis against $A$. strictum increased by increasing initial sucrose concentration reaching maximum value $(33.64 \mathrm{AU})$ with maximal bacterial growth $\left(30 \times 10^{7} \mathrm{cfu}^{\mathrm{ml}} \mathrm{m}^{-1}\right)$ with sucrose concentration of $\quad 9.0 \mathrm{~g}^{-\mathrm{I}^{-1}}$. Higher concentration of sucrose led to a decrease in both variables. Results reveal that the antagonistic activity correlated positively with the increase of bacterial growth. The obtained results thus confirm those of earlier reports (Sellam et al., 1978 and Abd-Alla et al., 2003).

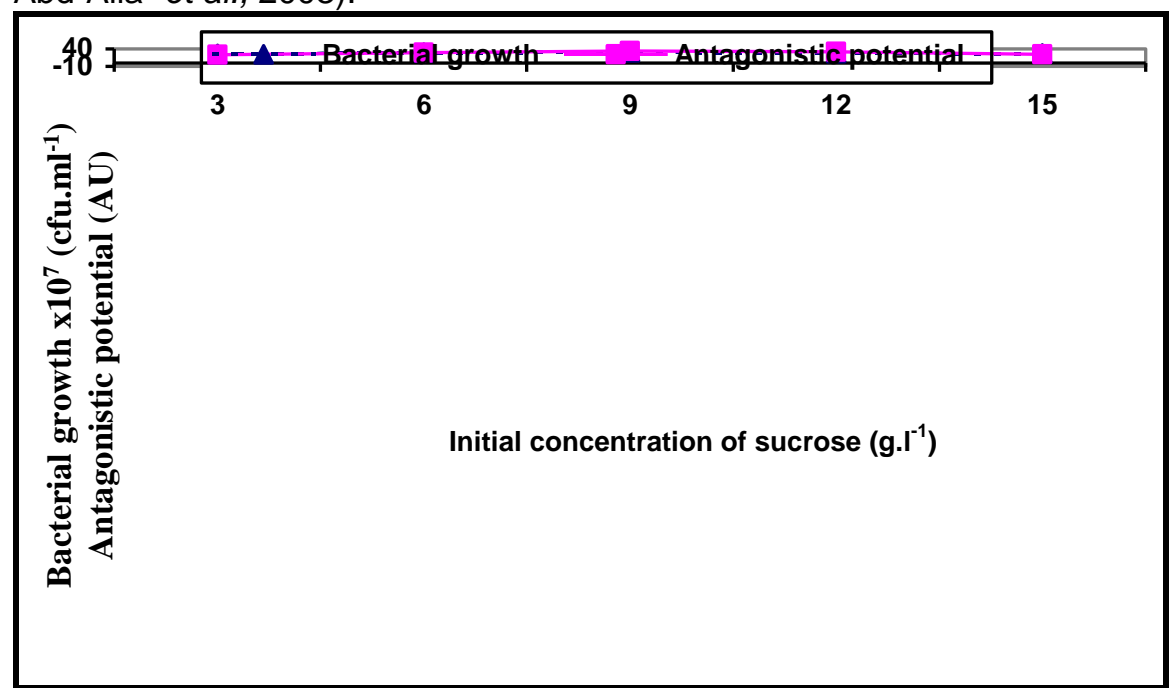

Figure 6: Effect of initial concentrations of sucrose on growth and antagonistic potential of $B$. subtilis against $A$. strictum expressed as absolute unit of inhibition zones (AU).

\section{Effect of nitrogen sources}

Among the seven tested nitrogen sources (Table 2), $\mathrm{KNO}_{3}$ was the best which maximized the antagonistic potential against $A$. strictum (34.81 
$\mathrm{AU}$ ) followed by peptone and yeast extract (33.64 and $31.36 \mathrm{AU}$, respectively). Whereas, yeast extract stimulated bacterial growth followed by peptone and urea. Addition of $\mathrm{NH}_{4} \mathrm{Cl}$ or $\left(\mathrm{NH}_{4}\right)_{2} \mathrm{SO}_{4}$ resulted in lowest antagonistic activity. Abd-Alla et al. (2003) achieved the highest antagonistic potential of $B$. subtilis against $S$. rolfsii with $\mathrm{KNO}_{3}$ as nitrogen source.

Table 2: Effect of nitrogen sources on growth and antagonistic potential of $B$. subtilis against $A$. stricum.

\begin{tabular}{|c|c|c|c|c|c|}
\hline \multirow[t]{2}{*}{ Carbon source ${ }^{(a)}$} & \multirow[t]{2}{*}{ Final pH } & \multirow{2}{*}{$\begin{array}{c}\text { Bacterial } \\
\text { growth X } 10^{7} \\
\left(\text { cfu.ml }{ }^{-1}\right)\end{array}$} & \multicolumn{3}{|c|}{$\begin{array}{c}\text { Antagonistic potential of } B . \\
\text { subtilis culture filtrate against } A \text {. } \\
\text { strictum }\end{array}$} \\
\hline & & & $Y(m m)$ & $\mathrm{Y}^{2}\left(\mathrm{~mm}^{2}\right)$ & $A U=Y^{2} / X^{2}$ \\
\hline Ammonium sulphate & 6.95 & 27 & 8.00 & 64.00 & 10.24 \\
\hline Ammonium chloride & 7.00 & 25 & 8.00 & 64.00 & 10.24 \\
\hline Sodium nitrate & 6.85 & 30 & 12.00 & 144.00 & 23.04 \\
\hline Potassium nitrate & 6.85 & 30 & 14.75 & 217.56 & 34.81 \\
\hline Peptone (control) & 6.80 & 31 & 14.50 & 210.25 & 33.64 \\
\hline Urea & 7.1 & 31 & 12.50 & 156.25 & 25.00 \\
\hline Yeast extract & 6.85 & 32 & 14.00 & 196.00 & 31.36 \\
\hline
\end{tabular}

$Y$, radius of inhibition zone

$\mathrm{Au}$, absolute unit of inhibition zone

(a), at the rate of $3.9 \mathrm{~g}$ carbon. $\mathrm{I}^{-1}$

\section{Effect of initial concentration of $\mathrm{KNO}_{3}$}

As illustrated in Figure (7), the stimulatory effect of varying $\mathrm{KNO}_{3}$ concentrations on antagonistic potential is interesting. While optimal growth of $B$. subtilis requires higher concentrations, only $20 \mathrm{~g}^{-1}$ of $\mathrm{KNO}_{3}$ were needed for maximum antagonism (36.0 AU). When initial $\mathrm{KNO}_{3}$ concentration was reduced to $5.0 \mathrm{~g}^{-1} \mathrm{I}^{-1}$, a considerable decrease in antagonistic activity was observed. The obtained results are in agreement with those reported by AbdAlla et al. (2003) with respect to the antagonism of $B$. subtilis against $S$. rolfsii.

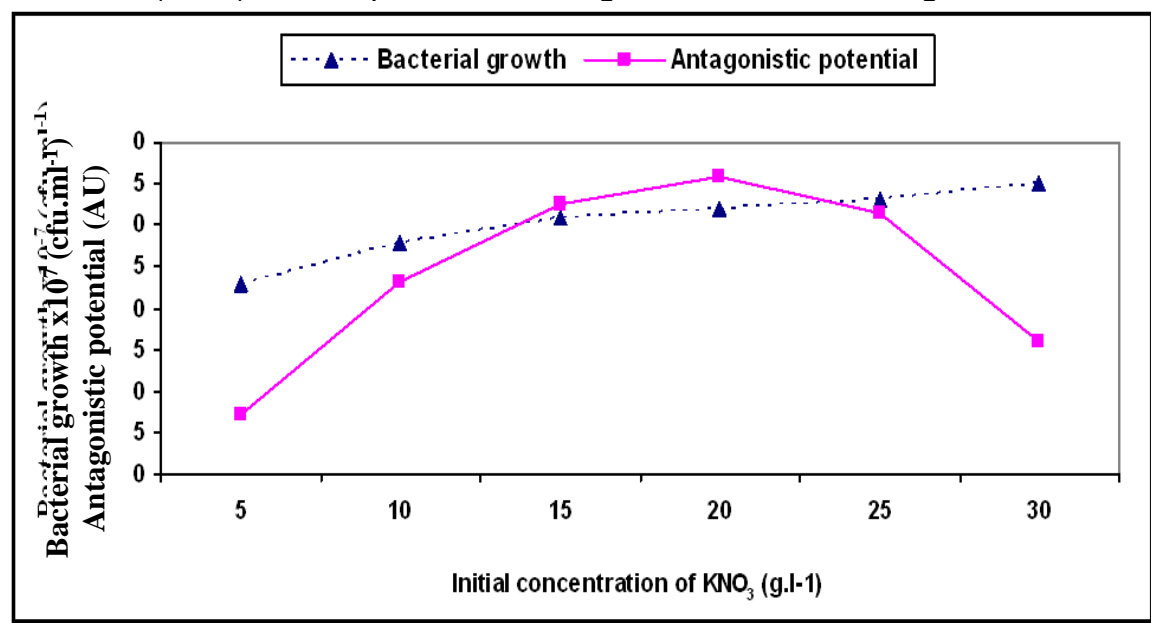

Figure 7: Effect of initial concentration of $\mathrm{KNO}_{3}$ on growth and antagonistic potential of $B$. subtilis against $A$. strictum expressed as absolute unit of inhibition zones (AU). 
Agro-industrial wastes as carbon and nitrogen sources

The feasibility of economic production of $B$. subtilis for application and use as biocontrol agent requires low production costs and high yield of the antifungal substance(s). These requirements could not be met upon using mineral synthetic media (El-Gamal and Hamed, 2003 and Dokhan, 2005). Therefore, sucrose in modified King's medium was replaced by predetermined quantities of each of three different cheap carbon sources. Figure (8) shows that $B$. subtilis exhibited the lowest bacterial growth and the poorest performance in sugar beet and sugar cane molasses (2.56 and 4.0 $A U$, respectively). The lowest bacterial growth and antagonistic activity of $B$. subtilis against $A$. strictum most probably due to presence of a number of inhibitory substances such as phenolic compounds in molasses. The inhibitory effect of these substances on microbial metabolism is well documented (Castro et al., 1994 and Dokhan, 2005). Results also reveal that glucose syrup supported simultaneously the highest antagonistic potential (36.0 AU) and bacterial growth. These improvements in both variables might be attributed to presence of certain minerals and/or organic growth factors that could be presented naturally in this by-product (Taherzadeh et al., 2003).

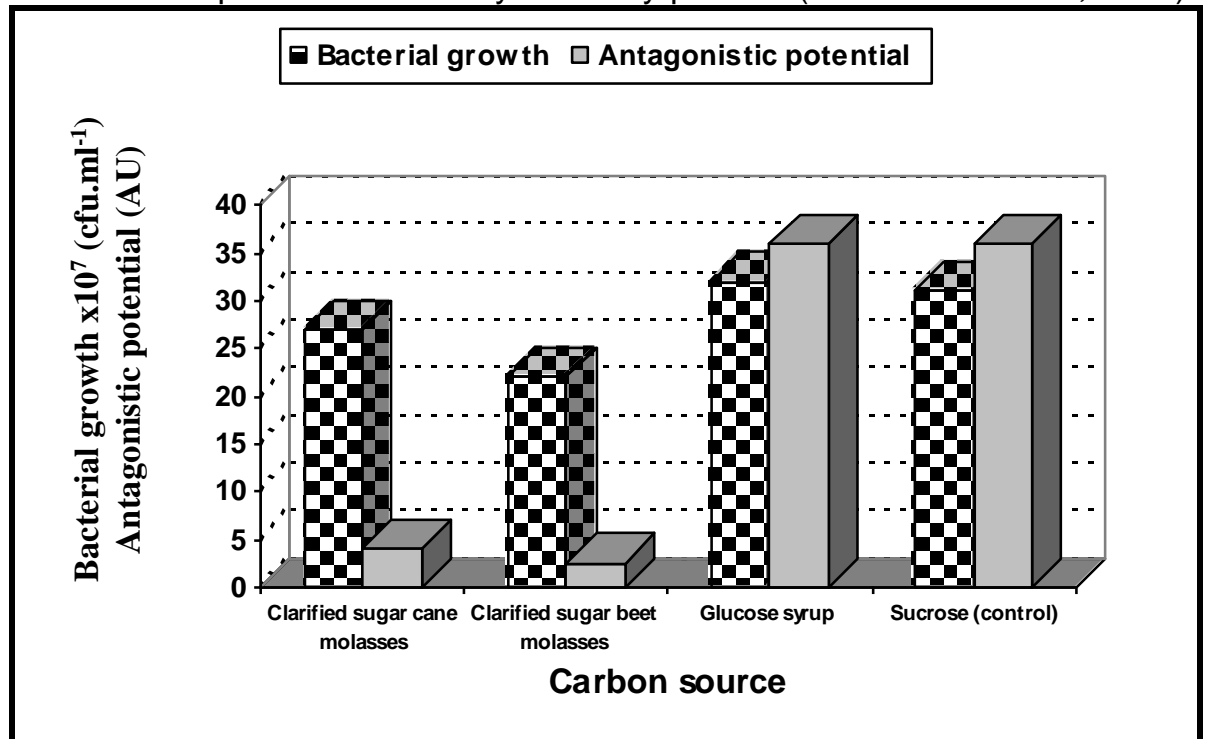

Figure 8:Utilization of agro-industrial wastes as carbon sources for enhancing growth and antagonistic potential of $B$. subtilis against $A$. strictum expressed as absolute units of inhibition zones (AU).

On the other hand, $\mathrm{KNO}_{3}$ in modified King's medium was also replaced by predetermined quantities of each of three cheap organic wastes as nitrogen source. Generally, all tested pretreated wastes induced growth and antagonistic activity of $B$. subtilis against $A$. strictum with different efficiencies (Figure 9). With corn steep liquor, $B$. subtilis exhibited the highest growth and antagonistic potential $\left(35 \times 10^{7} \mathrm{cfu}^{-\mathrm{ml}^{-1}}\right.$ and $36.48 \mathrm{AU}$, 
respectively). This represented the highest achievement propagation conducted. These results are in line with those reported by El-Gamal and Hamed (2003).

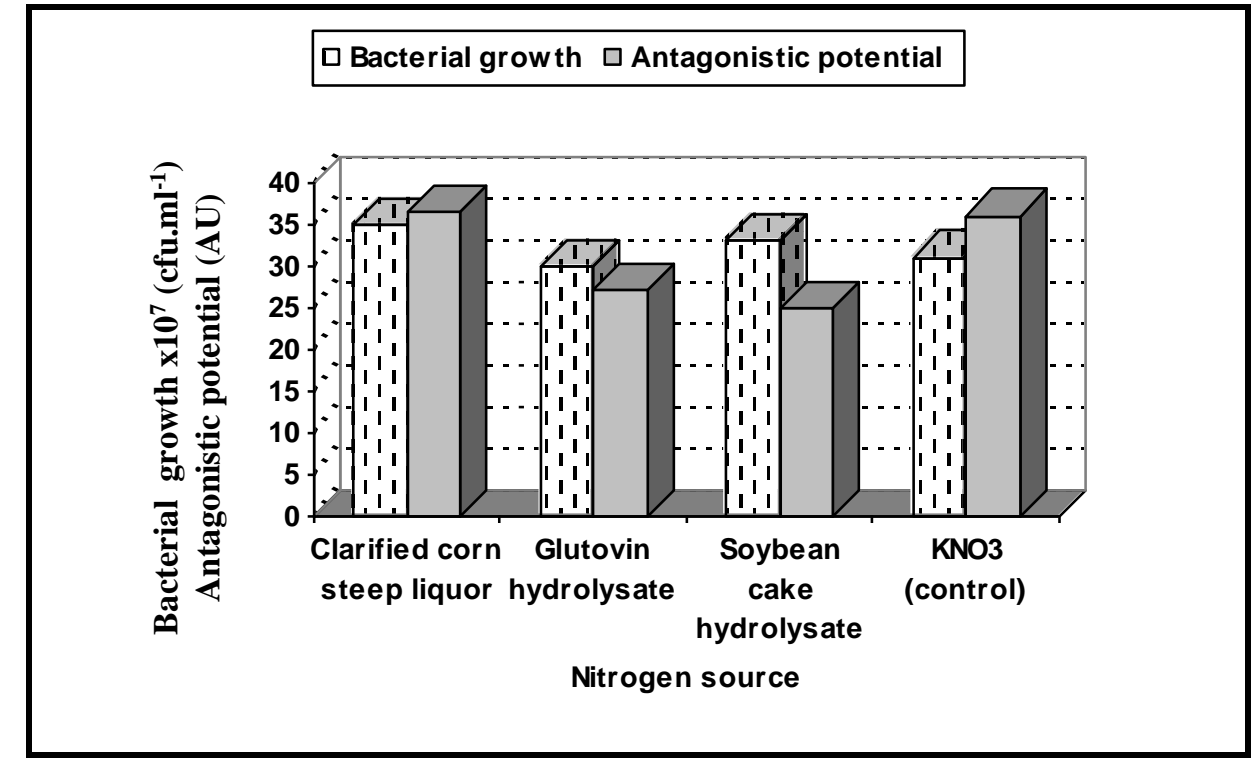

Figure 9: Utilization of agro-industrial wastes as nitrogen sources for enhancing growth and antagonistic potential of $B$. subtilis against $\boldsymbol{A}$. strictum expressed as absolute units of inhibition zones (AU).

According to the aforementioned results, glucose syrup, and corn steep liquor were selected as most appropriate and cheap carbon and nitrogen sources, respectively for propagation of $B$. subtilis.

Work is in progress concerning extraction, purification and characterization of antifungal substance(s) of $B$. subtilis in addition to formulation of this promising bacterial strain as biocontrol agent against $A$. strictum.

\section{REFERENCES}

Abd-Alla, E.F.; Ezzat, S.M.; Sarhan, M.M. and ABd-El-Mottleb, A.A. (2003). Biocontrol of peanut southern blight (Sclerotium rolfsii) by Bacillus subtilis. Egypt. J. Microbiol., 38 (3) 207-216.

Abo-Elnaga, Heidi I.G. (2006). Bacillus subtilis as a biocontrol agent for controlling sugar beet damping off disease. Egypt. J. Phytopathol., 34 (1) $51-59$.

Ahmed, S.H.; Gamal, Rawia, F.; Mashhoor, W.A. and Mansour, S.M. (1992). Carbon and nitrogen sources affecting the biomass production by some local fungal isolates. Res. Bull. Home Economic. 2:17-28. 


\section{Ali, M.A.et al.}

Ali, M.A.; Osman, Ettimad, A.H.; Ibrahim, Thanaa, F.; Khalafalla, G. and Amin, G. (2004). Sorghum grain-associated mycoflora with special emphasis on the virulence of Acremonium strictum.

Ali, M.A.; Osman, Ettimad, A.H.; Ibrahim, Thanaa, F.; Khalafalla, G. and Amin, G. (2005). In vivo antagonistic capabilities of various Bacillus subtilis and Streptomyces spp. formulations against Acremonium strictum. J. Agric. Sci., Mansoura Univ., 30 (2) 851-860.

Barnett, H.J. (1960). Illustrated Genera of imperfect Fungi. Burgess, Minneapolis, USA.

Booth, C. (1971). Methods in Microbiology. 4: 795 pp.; Acad. Press, London and New York.

Brock, T.D. (1973). Basic microbiology with Application. Prentic-Hall Inc., Englewood Cliffs, New Jersey, USA.

Castro, F.B.; Hotten, P.M.; Orskov, E.R. and Rebeller, M. (1994). Inhibition of rumen microbes by compounds formed in the steam treatment of wheat straw. Biores. Technol., 50: 25-30.

Chincholkar, S.B. and Mukerji, K.G. (2007). Biological control of plant disease, Haworth Food and Agricultural Products Press ${ }^{\mathrm{TM}}$, New York, London and Oxford, pp. 223-238.

Dinakaran, D.; Ramakrishnan, G.; Sridhar, R. and Jeyarajan, R. (1995). Management of sesamum root-rot with biocontrol agents. J. of Oil Seeds Research. 12 (2) 262-270.

Dokhan, A.M. (2005). Utilization of agriculture and food industry wastes for production of high economical value products through microbial activity. Ph. D. Thesis, Fac. Agric., Cairo Univ., Cairo, Egypt.

Duncan, D.B. (1955). Multiple range and multiple $F$ test. Biometrics. 11:1-42.

El-Assiuty, E.M. (1982). Studies on stalk rot disease of grain sorghum in Egypt. Ph. D. Thesis, Fac. Agric.; Moshtohor, Zagazig Univ., Benha Branch.

El-Gamal, Nadia G. and Hamed, Eman R. (2003). Control of root-rot disease of tomato plants using bioagents growing on economic media. Egypt $\mathrm{J}$. Microbiol., 38 (4) 351-361.

El-Kazzaz, M.K.; Hassan, M.A.; Ghoniem, K.E. and El-Zahaby, H.M. (2000). Biological control of sugar beet root rot caused by certain soil-borne fungi. The $9^{\text {th }}$ Cong. Of Phytopathol. The Egypt. Phytopathol. Soc., Giza, Egypt, May.

El-Shafey, H.A.; Abd-El-Rahim M.F. and Refaat, M.M. (1979). A new Cephalosporium wilt of grain sorghum in Egypt. Proc. Of $3^{\text {rd }}$ Egypt. Phytopathol. Cong., p. 514-532.

El-Shafey, H.A.; El-Assuity, E.M.; Zein El-Abedeen, A.; Ibrahim, Thanaa F. and Fahmy, Zeinab, M. (1999). Further studies on Acremonium wilt of grain sorghum. Egypt. J. Agri. Res., 77 (2) 533-547.

Ezzat, S.M.; Sarhan, M.M.; Tohamy, M.R.A.; El-Essawy, A.A. and Mohamed, E.F.A. (2001). Isolation, optimization and characterization of an antifungal substance from Bacillus subtilis against Fusarium oxysporum f.sp. Lycopersici. Egypt. J. Microbiol., 36 (2) 191-209. 
Ibrahim, Thanaa F. (1990). Studies on the biological control of the late wilt disease of maize. Ph.D. Thesis, Fac. Agric.; Ain Shams Univ., Cairo, Egypt.

Ibrhim, Thanaa F. and Zein El-Abedeen, A. (2000). Biological control of Acremonium wilt of grain sorghum caused by Acremonium strictum. Annals Agric. Soc. Moshtohor, 38 (1) 199-208.

Jacobs, M.B. and Gerstein, M.J. (1960). Handbook of Microbiology. D. Van Nostrand Comp. Inc., New York, pp. 139-207.

King, E.O.; Ward, M.K. and Raney, D.E. (1945). Two simple media for the demonstration of pyocyanin and flourescein. Lab. Clin. Medic., 44: 301307.

Kulkarni, S.A.; Srikant, K. and Kulkarni, S. (1996). Biological control of Sclerotinum rolfsii Sacc.; a causal agent of stem rot of ground nut, Karmataka J. of Agricultural Sciences.7 (3) 365-376.

Mansour, I.M.; El-Shafey, H.A. and Moursy, Maysa A. (1986). Cultural variation in Cephalosporium acremonium against fungicides. Egypt Soc. Appl. Microbiol.; Proc. VI Conf. Microbiol., Cairo, May, Plant Pathol., II (VI) 133-141.

McKeen, C.D.; Reily, C.C. and Pusey, P.L. (1986). Production and partial characterization of antifungal substances antagonistic to Monilinia fructicola from B. subtilis. Phytopathology.76: 136-142.

Natural, M.P.; Frederiksen, R.A.; and Rosenow, D.T. (1982). Acremonium wilt of sorghum. Plant Dis., 66: 863-865.

Osman, Ettimad A.H. (2004). Studies on the interaction between soil microflora and the pathogenic organisms causing sorghum diseases. M.Sc. Thesis, Fac. Agric., Cairo Univ., Cairo, Egypt.

Pyke, M. (1958). The technology of yeast In: The chemistry and Biology of Yeasts (Cook, A.H.; ed), Academic Press, New York, USA.

Ratnadass, A.; Marley, P.S.; Hamada, M.A.; Ajayi, O.; Cisse, B.; Assamoi, F.; Atokple, I.D.K.; Beyo, J.; Cisse, O.; Dakouo, D.; Diakite, M.; DossouYovo, S.; Le Diambo, B.; Vopeyande, M.B.; Sissoko, I. and Tenkouano, A. (2003). Sorghum head bugs and grain molds in west and central Africa: I-host plant resistance and bug-mold interactions on sorghum grains. Crop Protec., 22: 837-851.

Richards, L.A. (1954). The Diagnosis and Improvement of Saline and Alkali Soils. USDA, Hand Book, p. 60.

Sabet, K.A.; Samra, A.S.; and Fadl, F.A. (1966a). Cephalosporium acremonium Corda, the cause of black bundle disease. In: Investigations on stalk rot disease of maize in U.A.R. Ministry of Agric. Egypt, Tech. Bull., 165-169.

Sabet, K.A.; Samra, A.S. and Khalil, I.I. (1966b). Late-wilt of maize and a study of the causal organism. In: investigation on stalk rot disease of maize in U.A.R. Ministry of Agric., Egypt, Tech. Bull., 46-93.

Sarhan, M.M.; Ezzat, S.M.; Tohamy, M.R.A.; El-Essawy, A.A. and Mohamed, F.A. (2001). Biocontrol of Fusarium tomato wilt disease by Bacillus subtilis. Egypt. J. Microbiol., 36 (1) 103-118. 


\section{Ali, M.A.et al.}

Sellam, A.A.; Abd-Elrasik, A. and Rushdi, E. (1978). Antagonistic effect of B. subtilis against Cephalosporium maydis. Egypt. J. Phytopathol., 10 (2) $97-105$.

Sendecor, C.W. and Cochran, G.W. (1980). Statistical Methods. $7^{\text {th }}$ ed. lowa State Univ. Press, Ames, lowa, USA.

Stanisich, V. and Holloway, B.W. (1972). A mutant sex factor of Pseudomonas aeroginosa. Gene. Res., 19: 91-100.

Taherzadeh, M.J.; Fox, M.; Hjorth, H. and Edebo, L. (2003). Production of mycelium biomass and ethanol from paper pulp sulfite liquor by Rhizopus oryzae. Bioresource Technology. 88: 167-177.

Thom, C. and Raper, K.B. (1945). A Manual of the Aspergilli, Williams and Wilkins Co., Baltimore, Md, USA.

William, G.E. and Asher, M.J.C. (1996). Selection of rhizobacteria for the control of Pythium ultimum and Aphanomyces cochloides on sugar beet seedlings. Crop Protect, 15(5) 479-486.

Xu, X. De.; Zhao, T.C.; Liu, Z.H.; Xu, X.D.; Zhao, T.C. and Liu, Z.H. (1995). Studies on Acremonium wilt in sorghum. Acta Phytophylacica Sinica. 22 (2) 123-126.

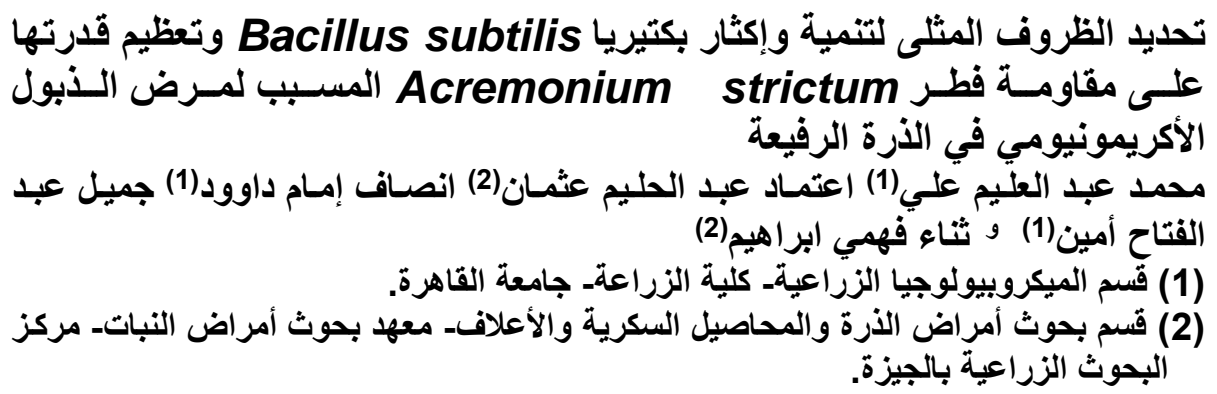

يعتبر فطر Acremonium strictum الكسبب لمرض الذبول الأكريمونيومي في الذرة الرفيعة من أهم



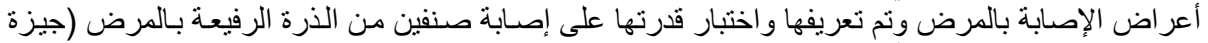

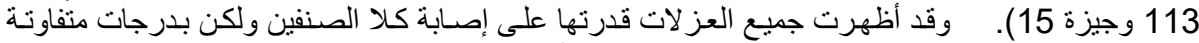

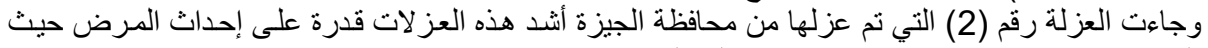

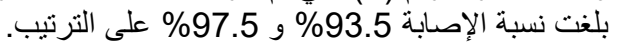

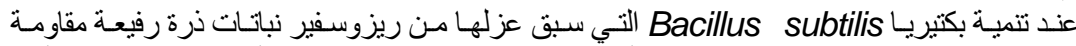

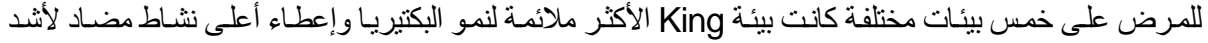

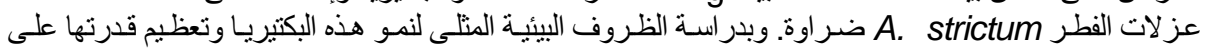

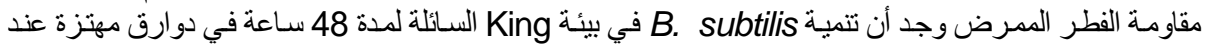

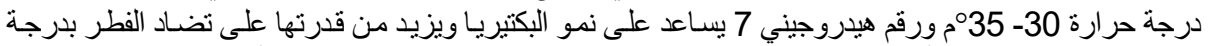

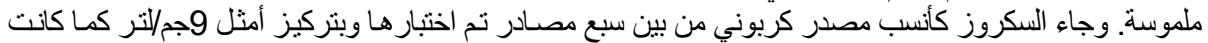

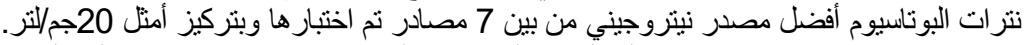

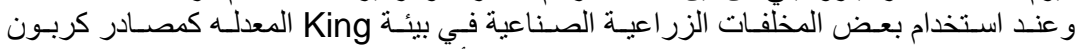

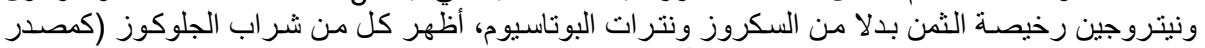

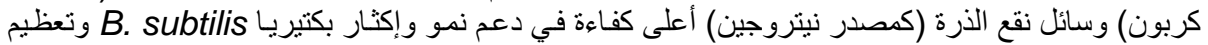

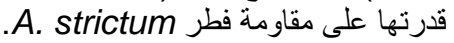

